Ivana Pavlić*

Katija Vojvodic ${ }^{* *}$

Barbara Puh ${ }^{* * *}$
JEL Classification: D12, M31, L81

Preliminary statement

https://doi.org/10.32910/ep.72.3.5

\title{
EXPLORING LOYALTY OF GENERATION $X$ IN A RETAIL STORE CONTEXT
}

Despite the increased interest in consumers pertained to Generation X, there is still much that is not understood about this particular market segment. In particular, this refers to their retail-related behaviour as well as the satisfaction and loyalty of customers in traditional brick and mortar retail environment. The purpose of this paper is to expand the knowledge base about Generation $X$ 's retail store attitudes and retail behaviour in order to identify their loyalty in a retail store context. For that reason, an empirical research was carried out using a convenience sample of 153 Generation X members from the DubrovnikNeretva County during the period from June 1 to October 1,2016. To analyse the data, ordinal logistic regression and ANOVA methods were used. The results revealed that several variables were found partially statistically significant, i.e. retail service quality, retail store quality, product price, product assessment, retail store format and frequency of purchase. This paper provides a framework for an improved understanding of Generation $X$ as consumers and their overall store experience. Moreover, it contributes to the existing literature by providing new insights into the loyalty of Croatian Generation X consumers.

Keywords: Generation X, retail store, customer satisfaction, loyalty, Croatian consumers.

*I. Pavlić, Ph.D., Full Professor, University of Dubrovnik, Department of Economics and Business (e-mail: ipavlic@unidu.hr).

${ }^{* *}$ K. Vojvodić, Ph.D., Associate Professor, University of Dubrovnik, Department of Economics and Business (e-mail: katija.vojvodic@unidu.hr).

**** B. Puh, Ph.D., Assistant Professor, University of Dubrovnik, Department of Economics and Business (e-mail: barbara.puh@unidu.hr). The paper was received on 13.11.2019. It was accepted for publication on 19.10.2020. 


\section{INTRODUCTION}

Consumers are often segmented by using their age as a key distinctive characteristic. In that context, generational cohort theory posits that each generation is characterized by somewhat predictable traits that are directly attributable to events happening during their formative years (Benckendorff and Moscardo, 2013, p. 135). Realised in broader terms, a generational cohort is often defined as a group of people born in the same era who have experienced a common social, political, historical, technological and economic environment (Lantos, 2015) that affects their collective behaviour (Martins, Yusuf and Swanson, 2012), and also creates values that remain relatively unchanged throughout their lives (Schewe and Meredith, 2004). Therefore, generational differences among consumers reflect similar values shaped by social and economic experiences (Solomon, Russell-Bennett and Previte, 2013).

In this paper, we focused on Generation X, also known as "Baby Buster", "Generation 2000", "the cable generation", and "the post baby-boomers" (Burke, 1994). Although the precise boundaries of Generation $X$ are still being debated, it mainly refers to individuals born between the years 1965 and 1980 (Feyerherm and Vick, 2005; Gibson, Regina and Edward, 2009; Lyons, Schweitzer and Ng, 2015; Cleveland and Hanscom, 2016). However, in this sense, scientists have also indicated some other time intervals that cover the range from 1961 to 1985 for this generation (Gurău, 2012; Ritchie, 1995; Appelbaum, 2005). In the context of Generation X, the majority of previous research is related to their lifestyle and attitudes, organisational and workplace issues and the style of communication (Smith, 2013; Williams, 2005; Jorgensen, 2003, Bova and Kroth, 2001; Cheah, Chong, Yeo and Pee, 2016).

Understanding Generation X consumers' retail behaviour is important for both retailers and marketers in order to approach this segment more successfully. In particular, retailers are aware of the importance of customer satisfaction on the outcome of their marketing and commercial strategies. The adaptation of the retail offer to the consumer's expectation leads to satisfaction, which is a crucial determinant of retail success (Theodoridis and Chatzipanagiotou, 2009). Nowadays, in the ever-changing retail environment, understanding customer satisfaction and the factors affecting satisfaction is an imperative for retailers. In order to anticipate satisfaction with a retail store and its offer, it is crucial to consider whether the store meets the expectations of the specific consumer segments in terms of attributes.

Despite the existing literature on store loyalty, there is a lack of studies that are examining the Generation X satisfaction and loyalty in the Croatian retailing 
context. Therefore, the main goal of this paper is to add new findings to the existing literature, to explore the main characteristics and purchase habits of Generation X in Croatia and to define the elements that influence building loyalty in retail stores. This paper is organized into five sections. Following the introduction, the continuing second section comprehends and considers the bodies of literature associated with the Generation X characteristics and their retail-related behaviour. The research methodology and data analysis are presented in the third section, whereas the fourth section brings the research results. Finally, the last section provides conclusions as well as research limitations and propositions for future work.

\section{LITERATURE REVIEW}

It is often emphasised that age groups must be understood for their specific needs and situations in their role as consumers (Moschis, Curasi and Bellenger, 2004). That way, retailers are able to design convenient marketing and commercial strategies to target particular market segment. However, Gen $\mathrm{X}$ is a challenging group to target considering that this segment has been put as "anti-advertising" (Ewing and Caruana, 1999) and more sceptical than any other group (Dunne, Lusch and Carver, 2014). Additionally, they reject any segmentation and marketing techniques that attempt to generalise their characteristics (Leung and Taylor, 2002). Apart from being sceptical of modern advertising (Williams, 2005), Gen Xers remain suspicious of marketing and media campaigns even as they embrace products and services that meet their needs (Barber, Dodd and Ghiselli, 2008).

Broadly speaking, members pertaining to Generation $\mathrm{X}$ focus on themselves rather than society (Boyd, 2010), and they care about the opinions of others (Lissitsa and Kol, 2016). They are unwilling to make changes and therefore find it difficult to establish secure jobs (Wyn, 2012), which may affect or limit their retail-related behaviour. Similarly, Brown (2012) and Araujo and Oliveira (2017) stress that Generation X "work to live rather than live to work". However, they tend to have more awareness toward their needs for financial planning (Safari, Mansori and Sesaiah, 2017) and are most likely to look for the lowest cost item or for the discount (Ordun, 2015).

In addition, members of Generation $\mathrm{X}$ are very motivated to search for purchase-related information (Ordun, 2015), especially online (Barber et al., 2008). In that context, they do more online shopping in comparison to the Baby Boomers (Dhanapal, Vashu and Subramaniam, 2015) and demonstrate a strong preference for Internet-only retailers (Brosdahl and Carpenter, 2012). It is important to note that Generation X consumers are highly affected by technology, diversity and 
choices, what leads to seemingly paradoxical and elusive behaviours when we look at their buying patterns (Hoffrichter, Wildes and Parks, 1999). In the context of extreme buying behaviour pattern, Valkeneers and Vanhoomissen (2012) note that Generation $\mathrm{X}$ seems to be prone to impulsive buying.

It is generally accepted that customer's satisfaction with the store is one of the most important drivers of loyalty to the particular store (McDougall and Levesque, 2000; Martinelli and Balboni, 2012). In the context of Generation X, few researchers have addressed the issues of their satisfaction and loyalty. Yang and Lau (2015) found that the members of the Generation X were value-centred when building loyalty. When we compare the characteristics of Generation $\mathrm{X}$ and Generation Y, Reisenwitz and Iyer (2009) highlighted that members of Generation $\mathrm{X}$ were more at risk of adverse behaviour and had greater brand/ product loyalty than members of Generation Y. In addition, according to Cleff, Huijnen and Walter (2016), members of Generation X showed a high probability to buy brand extensions. With regard to retail format preferences, desired retail attributes, satisfaction and loyalty, members of the Silent Generation were significantly more satisfied when compared to Baby Boom and Generation X consumers (Brosdahl and Carpenter, 2012).

In general, the variables that have the most influence on customer satisfaction are mostly related to the various store attributes such as the physical environment of the store, in-store convenience, personnel, atmosphere, product variety, assortment, quality and pricing policy (Martinez-Ruiz, Jimenez-Zarco and IzquierdoYusta, 2010). In that context, previous studies have also identified different moderating variables such as age, gender, education, income, etc. (Mittal and Kamakura, 2001; Seiders, Voss, Grewal and Godfrey, 2005). The majority of studies have demonstrated a positive relationship between store loyalty and both consumer satisfaction and store atmosphere (Francioni, Savelli and Cioppi, 2018). Therefore, the main hypothesis is stated as follows: the loyalty of Generation X depends on their satisfaction with the dimensions of the retail stores as well as purchasing patterns, and their socio-demographic characteristics.

\section{METHODOLOGY AND DATA ANALYSIS}

This paper follows Feyerherm and Vick (2005), Gibson et al. (2009), Ordun (2015), and Cleveland and Hanscom (2016) definition of Generation X, i.e. focusing on the individuals born between 1965 and 1980. Empirical research was conducted using a convenience sample of 300 members of the Generation X stemming only from the Dubrovnik-Neretva County during the period from June 1 to 
October 1, 2016 through personal interviews with consumers that were approached once they had made their purchase. In order to avoid any potential biases, measurements were taken during different parts of the day (in the morning, afternoon and evening) and throughout different days of the week. Of the initial sample, 153 questionnaires were utilized for further analysis. The sample profile is summarized in Table 1.

Data were collected through a highly structured questionnaire based on the literature review and the previously done research in the field (Mihić, 2006; Mihić and Kursan, 2010). The questionnaire consisted of four parts. The first part analysed six dimensions that were focused on the satisfaction of Generation $\mathrm{X}$ in a retail store context. These dimensions included retail service quality, retail store quality, store atmosphere, product assortment, product price and additional services. Each dimension was structured of several items that presented attributes of customer satisfaction. In total, 36 elements were divided into six dimensions.

Seven items were included in the first dimension of the retail service quality - RSerQ (courtesy of store personnel, helpfulness and sincerity of store personnel, education of store personnel, tidiness, efficiency of store personnel and promptness at the cash registers $-\mathrm{KMO}=.582 ; \alpha=.691)$. The second dimension of the retail store quality (RStQ) consisted of seven items (store layout, cleanliness of store, store location, number of stores, store work hours, parking facilities and store exterior appearance $-\mathrm{KMO}=.597 ; \alpha=.725)$. In the third dimension, we encompassed store atmosphere (SA), and comprised six items (in-store attractiveness, in-store atmosphere, scent, in-store aisle width, in-store ease of navigation and cash register organization $-\mathrm{KMO}=.687 ; \alpha=.789$ ). The fourth dimension, namely product assortment (PA), consisted of nine items (assortment, product quality, placement of products on shelves, selection of local products, selection of retail store brands, of bread and gourmet products and of fresh fruit and vegetables, selection of health products and selection of fresh meat $-\mathrm{KMO}=.723 ; \alpha=.785)$. The fifth dimension, product price (PR), included five items (price level, signage/readability, price credibility, frequency of price promotions and quality of the product on price promotion $-\mathrm{KMO}=.650 ; \alpha=.775)$. Finally, the sixth element named additional services was composed of two items (bill payment and home delivery - KMO =.500; $\alpha=.489$ ). This part of the questionnaire included multiple choice questions using a five-point Likert scale (where 1=very dissatisfied, $5=$ =ery satisfied), where respondents expressed the level of their satisfaction or dissatisfaction.

The level of loyalty of Generation X was analysed in the second part of the questionnaire. It was measured using eight statements (i.e., I prefer to buy in this retail store; I'm a member of the customer loyalty programme; I'm satisfied with the benefits of a loyalty programme; I'm satisfied with the types and frequency 
of rewards; I feel comfortable buying in this store; Store atmosphere evokes positive emotions; I will recommend the store; and It's enjoyable to buy in this store $-\mathrm{KMO}=.780, \alpha=847)$. Likewise, the answers were offered on the five-level Likert scale (1=totally disagree, $5=$ totally agree). For the simplicity of data analysis and the explanation of the results, the loyalty statements were merged and recoded into 3 degrees (values from 1 to 2.49 into code 3 , from 2.5 to 3.49 into code 2 and those from 3.5 to 5 into code 1$)$.

The third part of the questionnaire focused on purchasing patterns - what are the most visited retail store formats (this element included three items: the convenience store, supermarket, and hypermarket) and the frequency of purchase (including three items - daily purchasing, weekly purchasing or purchasing once in two weeks). Socio-demographic information (i.e. gender, level of education, occupation and personal monthly income) was included in the last part of the questionnaire.

Ordinal logistic model is as follows:

$\ln (\theta j)=\alpha+\left(-\beta_{1} X_{1}-\beta_{2} X_{2}-\beta_{3} X_{3}-\beta_{4} X_{4}-\beta_{5} X_{5}-\beta_{6} X_{6}-\beta_{7} X_{7}-\beta_{8} X_{8}-\beta_{9} X_{9}-\beta_{10} X_{10}\right)$

where is:

$X_{1}-R \operatorname{Ser} Q$ (Retail Services Quality)

$X_{2}-R S t Q$ (Retail Store Quality)

$X_{3}-S A$ (Store Atmosphere)

$X_{4}-P A$ (Products Assortment)

$X_{5}-P R$ (Product Price)

$X_{6}-R S F$ (Retail Store Format)

$X_{7}-$ FoP (Frequencies of Purchase)

$X_{8}$ - gender

$X_{9}-$ education

$X_{10}$ - personal monthly income

$\beta_{0}$ - evaluated parameters (intercept term)

$\beta_{j}$-estimated coefficients for predictor variables

Ordinal logistic regression examines the odds that a dependent variable (ED) will get for the values $j$ or less regarding the values greater than $j$, respectively:

$$
\theta_{j}=\frac{P(Y \leq j)}{(Y>j)}
$$


In order to define the loyalty of Generation $X$ with regard to the previously mentioned dimensions, Ordinal Logistic Regression was applied using the Statistical Package for Social Sciences (SPSS, version 23.0).

\section{RESEARCH RESULTS}

The frequencies of all the above-mentioned variables are shown in Table 1.

Table 1

VARIABLES IN THE MODEL

\begin{tabular}{|l|c|c|}
\hline Dependent variable & Frequency & Percentage (\%) \\
\hline Loyalty & & \\
Yes (1) & 23 & 15.2 \\
Yes/No (2) & 83 & 53.7 \\
No (3) & 47 & 31.1 \\
\hline Independent variable & Frequency & Percentage (\%) \\
\hline a) Demographic characteristics & & \\
\hline Gender & 69 & 45.1 \\
Male (2) & 84 & 54.9 \\
Female (1) & 3 & \\
\hline Education edu. & 55 & 2.0 \\
Primary school or less (1) & 49 & 35.9 \\
Secondary school (2) & 45 & 32.0 \\
Bachelor degree (3) & 1 & 29.4 \\
Graduate degree (4) & & 0.7 \\
Postgraduate (5) & 3 & \\
Monthly income in HRK ${ }^{1}$ mont.inc. & 34 & 2.0 \\
under 3,000 (1) & 52 & 34.2 \\
3,001-4,000 (2) & 47 & 30.6 \\
$4,001-6,000(3)$ & 14 & 9.2 \\
6,001-8,000 (4) & 3 & 2.0 \\
8,001-10,000 (5) & & \\
10,001- (6) &
\end{tabular}

1 HRK stands for Croatian Kuna. In January 2016 exchange rate of EUR 1 to HRK was 7.515 (https://www.hnb.hr/en/web/guest/core-functions/monetary-policy/exchange-rate-list/exchange- 


\begin{tabular}{|c|c|c|}
\hline \multicolumn{3}{|l|}{ b) Satisfaction } \\
\hline \multicolumn{3}{|l|}{ Retail Services Quality RSerQ } \\
\hline 1 - Very dissatisfied & 1 & 0.7 \\
\hline 2 - Dissatisfied & 2 & 1.3 \\
\hline 3 - Neither dissatisfied nor satisfied & 51 & 33.1 \\
\hline $4-$ Satisfied & 97 & 64.9 \\
\hline 5 - Very satisfied & 2 & 1.3 \\
\hline \multicolumn{3}{|l|}{ Retail Store Quality RStQ } \\
\hline 1 - Very dissatisfied & 1 & 0.7 \\
\hline 2 - Dissatisfied & 1 & 0.7 \\
\hline 3 - Neither dissatisfied nor satisfied & 50 & 32.7 \\
\hline 4 - Satisfied & 100 & 65.4 \\
\hline 5 - Very satisfied & 1 & 0.7 \\
\hline \multicolumn{3}{|l|}{ Store Atmosphere $\mathbf{S A}$} \\
\hline 2 - Dissatisfied & 8 & 5.2 \\
\hline 3 - Neither dissatisfied nor satisfied & 51 & 33.8 \\
\hline $4-$ Satisfied & 92 & 59.6 \\
\hline 5 - Very satisfied & 2 & 0.7 \\
\hline \multicolumn{3}{|l|}{ Products Assortment PA } \\
\hline 2 - Dissatisfied & 5 & 3.3 \\
\hline 3 - Neither dissatisfied nor satisfied & 61 & 39.8 \\
\hline 4 - Satisfied & 87 & 56.9 \\
\hline \multicolumn{3}{|l|}{ Product Price PR } \\
\hline 1 - Very dissatisfied & 2 & 1.3 \\
\hline 2 - Dissatisfied & 5 & 3.3 \\
\hline 3 - Neither dissatisfied nor satisfied & 90 & 58.8 \\
\hline $4-$ Satisfied & 55 & 35.9 \\
\hline 5 - Very satisfied & 1 & 0.7 \\
\hline \multicolumn{3}{|l|}{ c) Purchase habits } \\
\hline \multicolumn{3}{|l|}{ Retail Store Format RSF } \\
\hline 1 - convenience store & 19 & 12.4 \\
\hline 2 - supermarket & 118 & 77.1 \\
\hline 3 - hypermarket & 16 & 10.5 \\
\hline Frequencies of Purchase FoP & 68 & 45.0 \\
\hline 1 - daily & 78 & 50.4 \\
\hline 2 - once a week & 7 & 4.6 \\
\hline 3 - once in two weeks & & \\
\hline
\end{tabular}

Source: Authors' research

The frequencies and percentages of dependent and independent variable(s) are summarized in Table 1 . The results suggest that only $15.2 \%$ of the respondents

rate-list, accessed January $30^{\text {th }}$ 2017.). 
are the loyal ones, whereas the rest of the respondents are either neutral (53.7\%) or disloyal (31.1\%). With regard to the gender structure, approximately 55\% of the respondents were female. The educational structure showed that more than a third of the respondents (35.9\%) completed secondary school, whilst the majority of them were highly educated (62.1\%). For approximately $76 \%$ of the respondents, monthly income was above 4,001 HRK. As regards customer's satisfaction, it can be noted that two-thirds of the respondents were satisfied with the retail service and store quality, while $60 \%$ of them were satisfied with the store atmosphere. Almost $57 \%$ of the respondents were satisfied with the product assortment and $36.6 \%$ with the product price. When we take a closer look at the variables, it can be found that around one-third of respondents are indifferent. The only exception is the variable product price with almost $60 \%$ of identified indifferent consumers. In addition, approximately $90 \%$ of consumers buy in large stores (supermarkets and hypermarkets). Moreover, half of them buy once a week, while $45 \%$ of them make purchases on a daily basis.

Before proceeding with the partial coefficients testing, the reliability and the validity of the model were examined. The indicators of the model-fitting information are presented in Table 2. The difference between the two log likelihoods - the chi-square - has a perceived significance level of less than 0.05 . This indicates that the null hypothesis, which states that the model without predictors is as good as the model with predictors, can be rejected.

Table 2

\section{MODEL - FITTING INFORMATION}

\begin{tabular}{|l|c|c|c|c|}
\hline Model & -2 Log Likelihood & Chi-Square & df & Sig. \\
\hline Intercept Only & 192.574 & & & \\
\hline Final & 101.577 & 90.997 & 25 & .000 \\
\hline $\begin{array}{l}\text { Link function: } \\
\text { Logit. }\end{array}$ & & & & \\
\hline
\end{tabular}

Source: Authors' research

The test results of parallel lines are presented in Table 3. The column Sig. shows the p-value for the assumption of the test of the parallel lines. The p-value is found to be above 0.05 (0.187) suggesting that the test is not statistically significant and the parallel lines assumption has not been violated, therefore regression analysis can be continued. 
Table 3

\section{TEST OF PARALLEL LINES}

\begin{tabular}{|l|c|c|c|c|}
\hline Test of Parallel Lines & -2 Log Likelihood & Chi-Square & df & Sig. \\
\hline Null Hypothesis & 101.577 & 31.666 & 25 & .187 \\
\cline { 1 - 2 } General & 69.911 & & & \\
\hline
\end{tabular}

Source: Authors' research

The goodness-of-fit-statistics are shown in Table 4. As it can be observed, goodness-of-fit measures are not statistically significant. Therefore, it can be concluded that the model is fitting. It was found that the levels of significance are above 0.05 , which indicates that there is no statistically significant difference found between the observed and the expected frequencies.

Table 4

\section{GOODNESS-OF-FIT STATISTICS}

\begin{tabular}{|l|c|c|c|}
\hline & Chi-Square & df & Sig. \\
\hline Pearson & 87.994 & 97 & .081 \\
\hline Deviance & 74.401 & 97 & .115 \\
\hline
\end{tabular}

Source: Authors' research

Given that the model fulfils all adequacy tests, coefficients for predictor variables have been estimated (Table 5). 
I. PAVLIĆ, K. VOJVODIĆ, B. PUH: Istraživanje odanosti generacije X u maloprodajnom okruženju EKONOMSKI PREGLED, 72 (3) 431-448 (2021)

Table 5

PARAMETERS ESTIMATES FOR THE MODEL

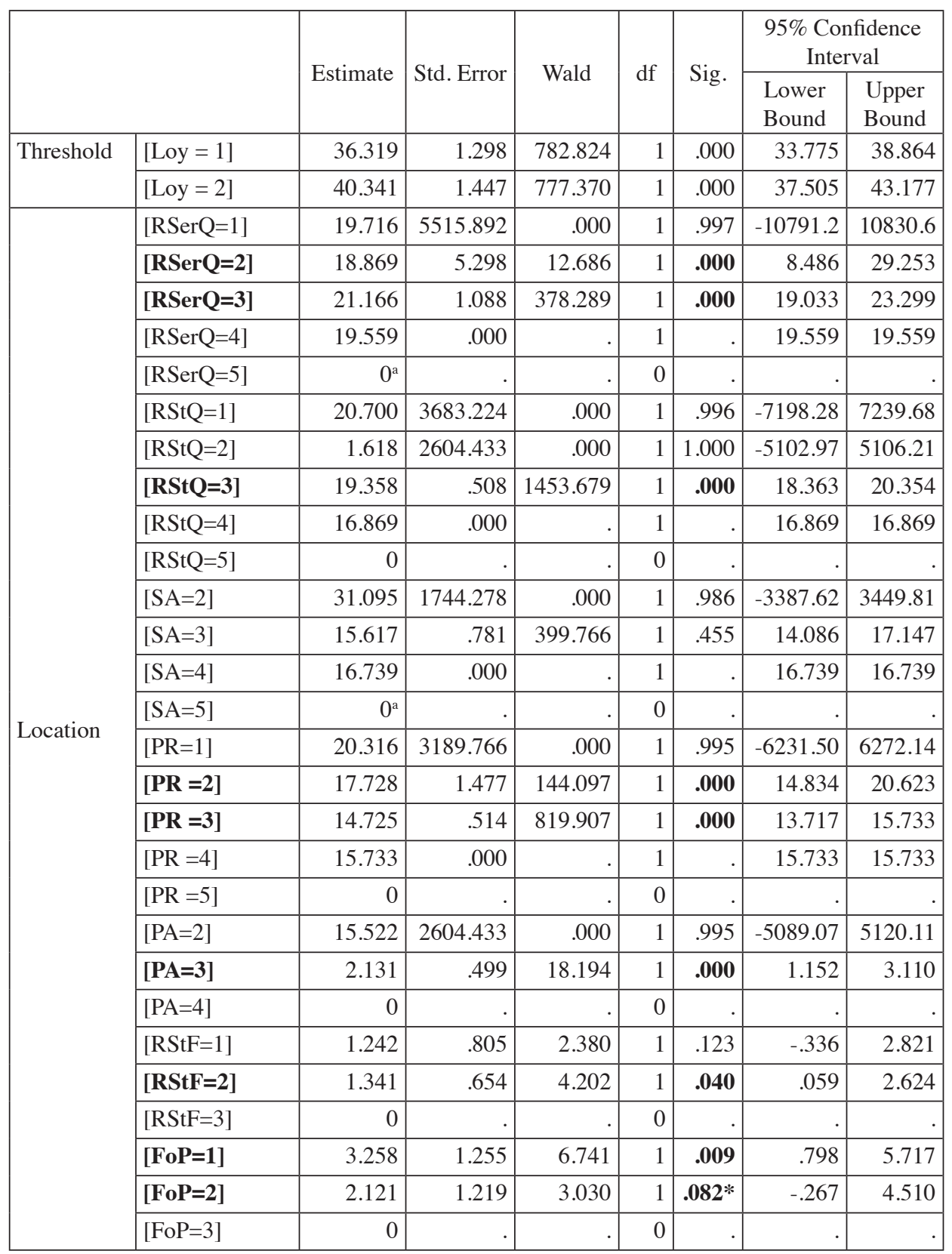




\begin{tabular}{|c|c|c|c|c|c|c|c|c|}
\hline & & \multirow{2}{*}{ Estimate } & \multirow{2}{*}{ Std. Error } & \multirow{2}{*}{ Wald } & \multirow{2}{*}{ df } & \multirow{2}{*}{ Sig. } & \multicolumn{2}{|c|}{$\begin{array}{c}95 \% \text { Confidence } \\
\text { Interval }\end{array}$} \\
\hline & & & & & & & $\begin{array}{l}\text { Lower } \\
\text { Bound }\end{array}$ & $\begin{array}{l}\text { Upper } \\
\text { Bound }\end{array}$ \\
\hline \multirow{11}{*}{ Location } & [gender $=1$ ] & .889 & .810 & 1.205 & 1 & .272 & -.698 & 2.475 \\
\hline & [gender=2] & $0^{\mathrm{a}}$ & . & . & 0 & & . & \\
\hline & [edu.=2] & 2.601 & 5.007 & .270 & 1 & .604 & -7.214 & 12.415 \\
\hline & [edu. =3] & 4.494 & 5.100 & .777 & 1 & .378 & -5.501 & 14.489 \\
\hline & [edu .=4] & .247 & 4.990 & .002 & 1 & .961 & -9.533 & 10.028 \\
\hline & {$[$ mont. inc. $=1]$} & 13.566 & 7138.607 & .000 & 1 & .998 & -13977.8 & 14004.9 \\
\hline & {$[$ mont. inc. $=2]$} & -5.828 & 5.441 & 1.147 & 1 & .284 & -16.492 & 4.837 \\
\hline & {$[$ mont. inc. $=3]$} & -2.561 & 5.220 & .241 & 1 & .624 & -12.792 & 7.670 \\
\hline & {$[$ mont. inc $=4]$} & -3.868 & 5.266 & .540 & 1 & .463 & -14.188 & 6.453 \\
\hline & {$[$ mont. inc $=5]$} & -5.937 & 5.318 & 1.246 & 1 & .264 & -16.359 & 4.485 \\
\hline & {$[$ mont. inc. $=6]$} & $0^{\mathrm{a}}$ & & & 0 & & & \\
\hline \multicolumn{9}{|c|}{ Link function: Logit. } \\
\hline \multicolumn{9}{|c|}{ a. This parameter is set to zero because it is redundant. } \\
\hline \multicolumn{9}{|l|}{$* \mathrm{p}<0,1$} \\
\hline
\end{tabular}

Source: Authors' research

The estimated coefficients that were statistically significant were considered for the proper data interpretation. If the estimated coefficient was found as positive, it suggested that the variable was associated with the higher category of the dependent variable and vice versa. In this case, the higher category of the dependent variable Loy (loyalty) implies that the particular respondent is not loyal. In this model, the following variables were found to be partially statistically significant: retail service quality, retail store quality, product price, product assessment, retail store format and frequency of purchase (Table 5).

For the variable retail service quality, reference category includes consumers who are very satisfied with the retail service quality. Estimated coefficients for consumers who are not satisfied and the ones who are neither dissatisfied nor satisfied were found to be statistically significant and positive. This means that consumers who are dissatisfied but also neither dissatisfied nor satisfied with the retail service quality are 18.9 times and 21.2 times, respectively more likely to be disloyal when compared to those consumers who are very satisfied.

Reference category for the variable retail store quality includes those consumers who are very satisfied with the retail store quality. The estimated coefficient for the consumers who are neither dissatisfied nor satisfied was found to be statistically significant and positive. It suggests that consumers who are neither 
dissatisfied nor satisfied with the retail store quality are 19.4 more times likely to be disloyal when compared to those who were very satisfied.

The estimated coefficient for the variable product assortment was found to be significant and positive for those consumers who are neither dissatisfied nor satisfied with product assortment. Therefore, consumers who are neither dissatisfied nor satisfied are 2.1 times more likely to be disloyal compared to those who are very satisfied.

For the variable product price, referent category consists of those consumers who are very satisfied with the product prices. For consumers who are dissatisfied and for those who are neither dissatisfied nor satisfied, estimated coefficient was found to be statistically significant and positive. This implies that consumers who are not satisfied and those who are neither dissatisfied nor satisfied with product prices are 17.7 times, and 14.7 times, respectively more likely to be disloyal when compared to those consumers who are very satisfied.

Furthermore, the variable retail store format was statistically significant for the category of supermarkets. Referent category is large stores, i.e. hypermarkets. This would appear to indicate that supermarket consumers are 1.3 times more likely to be disloyal when compared to hypermarket consumers.

Finally, for the variable frequency of purchase referent category formed consumers who buy once in two weeks. Estimated coefficients were found to be statistically significant and positive for consumers who make their purchases on a daily and weekly basis. In other words, consumers who buy on a daily and weekly basis are 3.3, and 2.1 times, respectively, more likely to be disloyal when compared to those consumers who purchase products once in two weeks. When considering the above mentioned results, it can be concluded that the hypothesis has been partially confirmed, i.e. the retail service quality, retail store quality, product price, product assessment, retail store format and frequency of purchase influence loyalty building among Generation $\mathrm{X}$ in Croatia.

\section{CONCLUSIONS}

As it was previously noted, the literature offers limited understanding of Generation X's consumer behaviour in traditional retail stores. To our knowledge, this is the first study dealing with Generation $\mathrm{X}$ in retailing context in Croatia. The most striking result that has emerged from the data is that almost one-third of the members of Generation $\mathrm{X}$ are indifferent consumers who feel disinterested in the satisfaction with retail stores. Moreover, almost half of them feel indifferent to- 
wards some retail dimensions, such as product assortment and its price. Therefore, these findings point to customer disloyalty and the need to use different marketing approaches. Additionally, it was found that Generation X consumers who demonstrate a strong preference for supermarkets and buy regularly (daily or weekly) have a higher likelihood of being disloyal.

These insights may be useful for retail managers and marketers who approach the Generation X consumers. Nowadays, the differentiation of the retail stores constitutes a crucial element in a retailer's success. Diverse store attributes will contribute to the differentiation of that store from its competitors. By improving retail services, store quality, product assortment and pricing, indifferent consumers could be converted into satisfied ones. This would serve as a solid base to enhance consumer's loyalty in the retail store context. Additionally, customer satisfaction in a retail setting may result in several important outcomes, including customers' repatronage intentions, sales performance, and loyalty. Through a better understanding of their behaviour, both retailers and marketers will be able to develop retail strategies to improve their services and to better satisfy the needs and requirements of this generational cohort. As a result, Generation X consumers will be better targeted and the overall retail experience will be enhanced.

However, these findings should be considered in the light of their own limitations. Given that the convenience sample was used, the results should be taken only as indicative. With regard to a sample selection, the research was conducted in one Croatian county, in the very south territory of Croatia, which possibly limits the representativeness of the sample and the final generalisation of the findings. Furthermore, issues related to purchasing behaviour of Generation $\mathrm{X}$ in an online retail setting have not been addressed in this paper, but they do deserve future investigations. Finally, additional limitations also refer to the lack of previous research of the Generation X consumer behaviour in Croatia, and the time frame of this research. Consequently, it was not possible to compare the results with the nonexisting similar (previous) studies relating to this generational cohort in Croatia.

To satisfy the needs of any future research, the sample should be extended by including other Croatian counties and research should be conducted over a longer period of time. That way, certain similarities and differences of retail buying behaviour of Generation X in Croatia could be identified. Thus, in order to generalize such findings, future research should focus on respondents' selection and it should include a wider geographic area. In addition, further research should focus on online purchasing behaviour of Generation X. Despite its limitations, this paper makes a valuable contribution to the existing literature by providing new insights into the level of loyalty of the consumers of the Croatian Generation X. In addition, this research results could be helpful when dealing with future studies on this topic, particularly in the context of Croatian retail environment. 
I. PAVLIĆ, K. VOJVODIĆ, B. PUH: Istraživanje odanosti generacije X u maloprodajnom okruženju EKONOMSKI PREGLED, 72 (3) 431-448 (2021)

\section{LITERATURE}

1. Appelbaum, S. H., Serena, M. and Shapiro, B. T. (2005). Generation "X" and the boomers: an analysis of realities and myths. Management Research News, 28(1), 1-33.

2. Araujo, S. and Oliveira, S. (2017). Job Market, Generations, and Talents. In C. Machado (Ed.), Competencies and (Global) Talent Management (pp. 95-114). London: Springer.

3. Barber, N., Dodd, T. and Ghiselli, R. (2008). Capturing the Younger Wine Consumer. Journal of Wine Research, 19(2), 123-141.

4. Benckendorff, P. and Moscardo, G. (2013). Generational cohorts and ecotourism. In R. Ballantyne and J. Packer (Eds.), International Handbook on Ecotourism (pp. 135-153). Cheltenham: Edward Elgar Publishing Limited.

5. Bova, B. and Kroth, M. (2001). Workplace learning and Generation X. Journal of Workplace Learning, 13(2), 57-65.

6. Boyd, D. (2010). Ethical Determinants for Generations X and Y. Journal of Business Ethics, 93(3), 465-469.

7. Brosdahl, D. J. C. and Carpenter, J. M. (2012). U.S. male generational cohorts: Retail format preferences, desired retail attributes, satisfaction and loyalty. Journal of Retailing and Consumer Services, 19(6), 545-552.

8. Brown, M. (2012). Responses to work intensification: does generation matter? The International Journal of Human Resource Management, 23(17), 3578-3595.

9. Burke, R. J. (1994). Generation X: Measures, Sex and Age Differences. Psychological Reports, 74(2), 555-562.

10. Cheah, C. S., Chong, V. S. W., Yeo, S. F. and Pee, K. W. (2016). An Empirical Study on Factors Affecting Organizational Commitment Among Generation X. Procedia - Social and Behavioral Sciences, 219, 167-174.

11. Cleff, T., Huijnen, M.-A. and Walter, N. (2016). Do you trust your brand or not? A comparative analysis of the adoption of brand extensions of Generation $\mathrm{X}$ versus $\mathrm{Y}$ in the FMCG industry. Interdisciplinary Management Research XII, 12, 871-890.

12. Cleveland, J. N. and Hanscom, M. (2016). What is Old at Work? Moving Past Chronological Age. In E. Parry, J. McCarthy (Eds.), The Palgrave Handbook of Age Diversity and Work (pp. 17-46). London: Palgrave Macmillan.

13. Dhanapal, S., Vashu, D. and Subramaniam, T. (2015). Perceptions on the challenges of online purchasing: a study from "baby boomers", generation " $X$ " and generation "Y" point of views. Contaduría y Administración, 60(S1), 107-132. 
14. Dunne, P. M., Lusch, R. F. and Carver, J. R. (2014). Retailing. Mason: SouthWestern Cengage Learning.

15. Ewing, M. T. and Caruana, A. (1999). Communicating with the Cohort: Exploring Generation X Attitudes Towards Advertising. Journal of International Consumer Marketing, 11(1), 41-53.

16. Feyerherm, A. and Vick, Y. H. (2005). Generation X women in high technology: Overcoming gender and generational challenges to succeed in the corporate environment. Career Development International, 10(3), 216-227.

17. Francioni, B., Savelli, E. and Cioppi, M. (2018). Store satisfaction and store loyalty: The moderating role of store atmosphere. Journal of Retailing and Consumer Services, 43, 333-341.

18. Gibson, J. W., Regina, G. and Edwards, M. (2009). Generational Differences in a Workplace: Personal Values, Behaviours and Popular Beliefs. Journal of Diversity Management, 4(3), 1-8.

19. Gurău, C. (2012). A life-stage analysis of consumer loyalty profile: comparing Generation X and Millennial consumers. Journal of Consumer Marketing, 29(2), 103-113.

20. Hoffrichter, M., Wildes, V. J. and Parks, S. C. (1999). Generation X and Their Future Buying Behaviors in the Foodservice Industry. Journal of Restaurant \& Foodservice Marketing, 3(3-4), 93-107.

21. Jorgensen, B. (2003). Baby boomers, generation X and generation Y? Foresight, $5(4), 41-49$.

22. Lantos, G. P. (20115). Consumer Behavior in Action: Real-life Applications for Marketing Managers. New York: Routledge.

23. Leung, J. W. K. and Taylor, G. (2002). Fashion buying criteria of X Generation consumers in Hong Kong. Journal of Fashion Marketing and Management: An International Journal, 6(1), 63-76.

24. Lissitsa, S. and Kol, O. (2016). Generation X vs. Generation Y - A decade of online shopping. Journal of Retailing and Consumer Services, 31, 304-312.

25. Lyons, S. T., Schweitzer, L. and Ng, E. S. W. (2015). How have careers changed? An investigation of changing career patterns across four generations. Journal of Managerial Psychology, 30(1), 8-21.

26. Martinelli, E. and Balboni, B. (2012). Retail service quality as a key activator of grocery store loyalty. The Service Industries Journal, 32 (14), 2233-2247.

27. Martinez-Ruiz, M. P., Jimenez-Zarco, A. I. and Izquierdo-Yusta, A. (2010). Customer satisfaction's key factors in Spanish grocery stores: Evidence from hypermarkets and supermarkets. Journal of Retailing and Consumer Services, 17(4), 278-285. 
I. PAVLIĆ, K. VOJVODIĆ, B. PUH: Istraživanje odanosti generacije X u maloprodajnom okruženju EKONOMSKI PREGLED, 72 (3) 431-448 (2021)

28. Martins, J. M., Yusuf, F. and Swanson, D. A. (2012). Consumer Demographics and Behaviour: Markets are People. London: Springer Science+Business Media B. V.

29. McDougall, G. and Levesque, T. (2000). Customer satisfaction and future intentions: the role of perceived value and service quality. Journal of Services Marketing, 14(5), 392-410.

30. Mihić, M. (2006). Segmentacija kupaca u supermarketima na osnovi njihova zadovoljstva prodajnim osobljem i izgledom prodavaonice: multivarijantna analiza. Ekonomski pregled, 57(12), 919-936.

31. Mihić, M. and Kursan, I. (2010). Market Segmentation Based on the Consumers' Impulsive Buying Behaviour. Econviews, 23(2), 385-399.

32. Mittal, V. and Kamakura, W. A. (2001). Satisfaction, repurchase intent, and repurchase behavior: investigating the moderating effect of customer characteristics. Journal of Marketing Research, 38(1), 131-142.

33. Moschis, G., Curasi, C. and Bellenger, D. (2004). Patronage motives of mature consumers in the selection of food and grocery stores. Journal of Consumer Marketing, 21(2), 123-133.

34. Ordun, G. (2015). Millennial (Gen Y) Consumer Behavior, Their Shopping Preferences and Perceptual Maps Associated With Brand Loyalty. Canadian Social Science, 11(4), 40-55.

35. Reisenwitz, T. H. and Iyer, R. (2009). Differences in generation X and generation Y: Implications for the organization and marketers. The Marketing Management Journal, 19(2), 91-103.

36. Ritchie, K. (1995). Marketing to Generation X. New York: Lexington Books.

37. Safari, M., Mansori, S. and Sesaiah, S. (2017). Generation difference in hiring financial planners in Malaysia. International Journal of Bank Marketing, 35(4), 583-595.

38. Schewe, C. D. and Meredith, G. (2004). Segmenting global markets by generational cohorts: determining motivations by age. Journal of Consumer Behaviour, 4(1), 51-63.

39. Seiders, K., Voss, G. B., Grewal, D. and Godfrey, A. L. (2005). Do satisfied customers buy more? Examining moderating influences in a retailing context. Journal of Marketing, 69(4), 26-43.

40. Smith, A. (2013). The Gen $X$ and Millennial Guide to a Thriving Career. Bloomington: iUniverse LLC.

41. Solomon, M., Russell-Bennett, R. and Previte, J. (2013). Consumer Behaviour: Buying, having, being. Frenchs Forest: Pearson Australia. 
42. Theodoridis, P. K and Chatzipanagiotou, K. C. (2009). Store image attributes and customer satisfaction across different customer profiles within the supermarket sector in Greece. European Journal of Marketing, 43(5/6), 708-734.

43. Valkeneers, G. and Vanhoomissen, T. (2012). Generations living their own life: The differences in lifestyle and consumer behaviour between busters and baby boomers. Journal of Customer Behaviour, 11(1), 53-68.

44. Williams, G. (2005). Using Multi-Generational Marketing to Target Donors. Nonprofit World, 23(5), 8-13.

45. Wyn, J. (2012). The making of a generation: policy and the lives and aspirations of Generation X. Journal of Educational Administration and History, 44(3), 269-282.

46. Yang, F. X. and Lau, V. M. C. (2015). LuXurY hotel loyalty - a comparison of Chinese Gen X and Y tourists to Macau. International Journal of Contemporary Hospitality Management, 27(7), 1685-1706.

\section{ISTRAŽIVANJE ODANOSTI GENERACIJE X \\ U MALOPRODAJNOM OKRUŽENJU}

Sažetak

Unatoč povećanom interesu za potrošače koji pripadaju generaciji X, postoji još puno nepoznanica o ovom tržišnom segmentu. To se posebice odnosi na njihovo ponašanje u kupnji te zadovoljstvo i odanost tradicionalnim prodavaonicama. Svrha je ovog rada proširiti saznanja o stavovima generacije X koji se odnose na osnovna obilježja prodavaonica i njihovo ponašanje u maloprodajnom okruženju s ciljem definiranja razine njihove odanosti. Iz tog je razloga provedeno empirijsko istraživanje na prigodnom uzorku od 153 pripadnika generacije $X$ iz Dubrovačkoneretvanske županije u razdoblju od 1. lipnja do 1. listopada 2016. Za analizu podataka korištene su ordinalna logistička regresija i ANOVA. Rezultati istraživanja ukazali su na nekoliko djelomično statistički značajnih varijabli, tj. kvalitetu maloprodajne usluge, kvalitetu prodavaonice, cijenu proizvoda, procjenu proizvoda, maloprodajni format $i$ učestalost kupnje. Ovaj rad pruža okvir za bolje razumijevanje generacije X kao potrošača i njihovog cjelokupnog iskustva u prodavaonici. Također, rad pridonosi postojećoj literaturi pružajući nove uvide u odanost hrvatskih potrošača generacije $X$. $\check{s} a c ̌ i$.

Ključne riječi: Generacija X, prodavaonica, zadovoljstvo kupaca, odanost, hrvatski potro- 